\title{
Guided Inquiry Learning Materials Based on Multiple Chemical Representations As One of Chemistry Learning Strategies Centered on Students
}

\author{
Mawardi Mawardi ${ }^{*}$, Bahrizal Bahrizal ${ }^{1}$, Zonalia Fitriza ${ }^{1}$ \\ ${ }^{1}$ Jurusan Kimia Universitas Negeri Padang, Jalan Prof. Dr Hamka Air Tawar, Padang, 25171, Indonesia \\ * Correspondence: mawardianwar@fmipa.unp.ac.id
}

Diterima 14 Desember 2018, Disetujui 25 November 2019, Dipublikasikan 30 November 2019

\begin{abstract}
Education in accordance with future needs will only be realized if there is a change in mindset in the learning process to be a student-centered, active-investigating, real world contexts, teambased learning, cooperatives, plural conscious effort, critical thinking, and to the exchange of knowledge. Center Curriculum (2007) reported that teachers faced 4 problems in implementing the content standards, namely: 1) Translation of basic competencies into indicators. 2) The description of the basic material in KD becomes a description of the main material in the Indicator; 3) Difficulties in implementing approaches, methods, or certain learning models in learning; 4) Difficulties in obtaining teaching materials that are oriented to certain teaching learning models such as inquiry. The development of chemical teaching materials for High School (SMA) based Classes Activities with guided inquiry models is one of the choices offered to overcome the aforementioned problems.
\end{abstract}

Keywords - chemistry learning strategy, guided inquiry, multiple representation, student centre learning, teaching learning material

\section{Pendahuluan}

Abad 21 merupakan abad yang berlandaskan ilmu pengetahuan dan teknologi, sehingga menuntut sumber daya manusia sebuah negara untuk menguasai berbagai bentuk keterampilan, termasuk keterampilan berpikir kritis dan pemecahan masalah dari berbagai permasalahan yang semakin meningkat. Salah satu usaha yang dilakukan Pemerintah pada saat ini adalah dengan menggulirkan Kurikulum 2013 yang merupakan kurikulum Nasional dengan terus menerus diperbaharui agar selaras dengan tuntutan Pendidikan Global dan tidak menyimpang dari nilai-nilai luhur bangsa Indonesia. Pembelajaran Abad 21 merupakan pembelajaran yang mengintegrasikan kemampuan literasi, kecakapan pengetahuan, keterampilan dan sikap, serta penguasaan terhadap teknologi.

Pembelajaran akan meletakkan dasar dan kompetensi, pengukuran kompetensi dengan urutan LOTs menuju HOTs. Proses pembelajaran akan dimulai dari suatu hal yang mudah menuju hal yang sulit, menjadi tangga bagi peserta didik untuk meningkatkan kompetensi menuju seseorang yang memiliki pola pikir kritis. Seseorang yang memiliki kemampuan berpikir kritis, kreatif, kolaborasi dan mampu berkomunikasi dengan baik akan meningkat pula karakternya, sehingga keilmuan dan kompetensi yang dikuasainya akan menjadikannya memiliki sikap/karakter yang bertanggungjawab, bekerja keras, jujur dalam kehidupannya sehingga akan menghasilkan lulusan yang memiliki karakter dan kompetensi. 
Pembelajaran dalam setiap mata pelajaran terkait dengan kompetensi dan konteks yang harus memacu peserta didik untuk memiliki ketrampilan berpikir dari yang sederhana (LOTs) menuju proses berpikir tingkat tinggi (HOTs). Melalui pembelajaran tersebut pada akhirnya dapat mengahasilkan lulusan yang berkarakter, kompeten dan literat untuk siap menghadapai tantangan abad 21.

Guru, sebagai salah satu komponen penting dalam pelaksanaan suatu kurikulum tentu perlu proaktif mencermati dan memahami perubahan yang terjadi agar dapat mempersiapkan diri dan beradaptasi dengan perubahan tersebut, diantaranya perubahan dalam materi pembelajaran dan proses pembelajaran, yang merupakan fokus utama dalam makalah ini. Pemerintah dalam hal ini Kementerian Pendidikan dan Kebudayaan, mulai tahun pelajaran Juli 2013, akan memberlakukan kurikulum pendidikan baru, yang disebut Kurikulum 2013.

Salah satu perubahan penting dalam kurikulm tersebut adalah proses pembelajaran, dari siswa diberi tahu menjadi siswa mencari tahu dan proses penilaian dari berfokus pada pengetahuan melalui penilaian output menjadi berbasis kemampuan melalui penilaian proses dan output, sehinggga memerlukan penambahan jam pelajaran

\section{Kurikulum 2013}

Dengan mempelajari dokumen Uji Publik Kurikulum 2013, terkait dengan kajian makalah ini, maka kita perlu mencermati beberapa hal penting dalam kurikulum tersebut, diantaranya: (1) Pengembangan Kurikulum 2013 melanjutkan pengembangan kurikulum berbasis kompetensi yang telah dirintis pada tahun 2004 dengan mencakup kompetensi sikap, pengetahuan, dan keterampilan secara terpadu. Landasan pengembangan kurikulum : yaitu perubahan metodologi pembelajaran dan penetaan kurikulum, untuk aspek konseptual, diantranya model kurikulum berbasis kompetensi dan proses pembelajaaran (ativitas belajar, output belajar, outcome belajar). (2) Strategi peningkatan efektivitas pembelajaran untuk mencapai transformasi nilai, diantaranya efektivitas pemahaman dan efektivitas penyerapan. Efektivitas pemahaman melalui pembelajaran yang mengedepankan pengalaman personal melalui observasi (menyimak, melihat, membaca, mendengar), bertanya, asosiasi, menyimpulkan, mengkomunikasikan.

Diantara permasalahan Kurikulum 2006 standar proses pembelajaran belum menggambarkan urutan pembelajaran yang rinci sehingga membuka peluang penafsiran yang beraneka ragam dan berujung pada pembelajaran yang berpusat pada guru.

\section{Ilmu Kimia dan Proses Pembelajaran Kimia di Sekolah}

Ilmu Kimia yang merupakan bagian dari Ilmu Pengetahuan Alam (IPA) atau sains merupakan suatu kumpulan pengetahuan yang tersusun secara sistematis, dan dalam penggunaannya secara umum terbatas pada gejala-gejala alam. Hakikat ilmu kimia meliputi empat unsur, yaitu: (1) produk: berupa fakta, prinsip, hukum, teori dan model; (2) proses: yaitu prosedur pemecahan masalah melalui metode ilmiah, yang meliputi pengamatan, penyusunan hipotesis, perancangan eksperimen, percobaan atau penyelidikan, pengujian hipotesis melalui eksperimentasi; evaluasi, pengukuran, dan penarikan kesimpulan; (3) aplikasi: berupa penerapan metode atau kerja ilmiah dan konsep IPA dalam kehidupan sehari-hari; (4) sikap: yaitu rasa ingin tahu tentang materi, fenomena alam, makhluk hidup, serta hubungan sebab akibat yang menimbulkan masalah baru yang dapat dipecahkan melalui prosedur yang benar.

Belajar merupakan suatu proses yang memungkin seseorang untuk mengubah tingkah lakunya cukup cepat, dan perubahan itu bersifat relatif tetap, sehingga perubahan yang serupa tidak perlu terjadi berulangkali setiap menghadapi situasi baru. Mengajar merupakan suatu perbuatan yang komplek, dimana dalam kegiatan mengajar seorang guru 
dituntut menggunakan keterampilannya secara integratif, sesuai dengan pesan yang terkandung dalam kurikulum, yang dalam aplikasinya secara unik dipengaruhi secara simultan oleh komponen-komponen yang terlibat dan terkait dengan kegiatan pembelajaran, antara lain: tujuan yang ingin dicapai, siswa yang belajar, faktor diri guru, sumber belajar, pendekatan dan strategi yang digunakan, fasilitas dan lingkungan belajar siswa serta kurikulum yang berlaku.

Hasil penelitian pihak-pihak yang berkompeten menyimpulkan bahwa siswasiswa Indonesia diduga baru mampu mengingat pengetahuan ilmiah berdasarkan fakta sederhana (1), sementara hasil penelitian PISA tahun 2009, menyimpulkan bahwa siswa Indonesia berada pada katagori Statistically significantlly below the OECD average dari tiga kategori above, not statistically significantlly different dan below [1].

Survei oleh TIMSS skor rata-rata perolehan anak Indonesia untuk IPA tergolong ke dalam katagori low benchmark artinya siswa baru mengenal beberapa konsep mendasar dalam Fisika dan Biologi, Sedangkan hasil survei TIMSS tahun 2007 terhadap pencapaian sains siswa kelas 8 siswa Indonesia masih berada pada level low benchmark atau Statistically lower than Ontario dari tiga kateori lower, same dan higher [2].

Proses pembelajaran selama ini masih terlalu berorientasi terhadap penguasaan teori dan hafalan dalam semua bidang studi sehingga menyebabkan kemampuan belajar peserta didik menjadi terhambat. Hasil pendidikan hanya tampak dari kemampuan menghafal fakta, konsep, teori atau hukum. Walaupun banyak anak mampu menyajikan tingkat hafalan yang baik terhadap materi yang diterimanya, tetapi pada kenyataannya mereka seringkali tidak memahami secara mendalam substansi materinya.

Menurut laporan Puskur [1] ditemukan empat kelompok masalah yang dihadapi oleh para guru ketika akan mengujudkan keterlaksanaan standar isi, yaitu:
1. Penjabaran kompetensi dasar menjadi indikator.

2. Penjabaran materi pokok dalam KD menjadi uraian materi pokok dalam Indikator, mencakup keluasan dan kedalaman materi, sehingga guru IPA mengalami kesulitan dalam menyusun silabus dan RPP;

3. Kesulitan dalam mengimplementasikan pendekatan, metode, atau model pembelajaran tertentu dalam pembelajaran, karena keterbatasan kemampuan sehingga tuntutan Standar Proses sulit dipenuhi guru;

Kesulitan memperoleh buku teks pelajaran yang berorientasi proses (model) tertentu seperti inkuiri, terutama yang ditulis dalam bahasa Indonesia dan sesuai dengan Kurikulum Nasional, sehingga sangat mempengaruhi ketercapaian Standar isi dan Standar Proses.

\section{Solusi/Teknologi}

Untuk memenuhi tuntutan Kurikulum 2013 Revisi 2016 tersebut, menuntut perubahan dalam proses pembelajaran dari siswa diberi tahu menjadi siswa mencari tahu dan proses penilaian menjadi berbasis kemampuan melalui penilaian proses dan output, sehingga diperlukan perubahan dalam hal representasi materi dan proses pembelajaran. Salah satu komponen penting yang harus tersedia adalah bahan ajar yang berorientasi proses saintifik yang dapat menfasilitasi terjadinya proses saintifik.

Persoalan yang dihadapi saat ini adalah belum tersedianya bahan ajar yang berorientasi proses seperti tuntutan Kurikulum 2013 tersebut dan belum mampunya sebagian besar pendidik dalam mengembangkan bahan ajar secara mandiri. Oleh sebab itu penelitian pengembangan pembuatan bahan ajar yang berorientasikan model pembelajaran inquiri terbimbing/guided-inquiry (yang mengandung 3 siklus belajar yaitu fase eksplorasi, penemuan/pembentukan konsep dan aplikasi) dan menerapkan tiga jenis representasi, yang dikenal dengan multirepresentasi kimia, untuk menyatakan ide-ide kimia, sehingga proses pembelajaran kimia menghasil tiga tingkatan pembelajaran (three learning levels), yaitu representasi 
simbolis, makroskopik dan sub-mikroskopis, atau molekular, yang sangat diperlukan siswa untuk memahami kimia. Modul pembelajaran yang dikembangkan ini untuk selajutnya disebut Modul Pembelajaran modul Inquiri Terbimbing berbasis Multipel representasi Kimia.

\section{Hasil dan Diskusi}

Proses pembelajaran menurut ilmu kognitif menyatakan bahwa orang belajar dengan cara: (1) membangun pemahaman mereka sendiri berdasarkan pengetahuan awal, pengalaman, keterampilan, sikap, dan keyakinan; (2) mengikuti siklus pembelajaran eksplorasi, pembentukan konsep, dan aplikasi; ( (3) menghubungkan dan memvisualisasikan konsep-konsep dan representasi yang beragam; (4) mendiskusikan dan berinteraksi dengan orang lain; (5) merefleksikan kemajuan dan menilai kinerja; (6) menginterkoneksikan konseptual dan prosedural pengetahuan dalam struktur mental yang besar [3], [4].

Peran Inquiri Terbimbing. Hasil penelitian memperlihatkan bahwa untuk mencapai pemahaman yang nyata, dalam pembelajaran peserta didik harus aktif merestrukturisasi informasi yang mereka serap. Untuk merestrukturisasi pengetahuan baru, peserta didik harus mengintegrasikannya dengan pengetahuan sebelumnya dan keyakinan, mengidentifikasi dan menyelesaikan kontradiksi, mengeneralisasi, membuat kesimpulan, dan mengajukan dan memecahkan masalah. Siklus belajar terdiri dari tiga tahap atau fase: eksplorasi, penemuan konsep atau pembentukan, dan aplikasi [5], [6], [7], [8], [9], [10],[11]..

Pada tahap "eksplorasi" dari siklus belajar, siswa mengembangkan pemahaman mereka tentang konsep dengan menanggapi serangkaian pertanyaan yang memandu mereka melalui proses eksplorasi suatu model atau melaksanakan suatu tugas. Hampir semua jenis informasi dapat diproses melalui langkah ini, seperti diagram, grafik, tabel data, satu atau lebih persamaan, metodologi, beberapa prosa, simulasi komputer, demonstrasi, atau kombinasi dari hal-hal ini. Pada fase eksplorasi, siswa mencoba untuk menjelaskan atau memahami materi yang disajikan dengan mengusulkan, mempertanyakan, dan menguji hipotesis.

1. Tahap kedua mungkin melibatkan "penemuan konsep" atau "pembentukan konsep". Ketika tahap kedua melibatkan penemuan konsep, maka tahap eksplorasi tidak menyajikan konsep tersebut secara eksplisit. Peserta didik secara efektif dipandu dan didorong untuk mengeksplorasi, lalu menarik kesimpulan dan membuat prediksi. Setelah peserta didik terlibat dalam fase ini, informasi tambahan dan nama konsep dapat diperkenalkan.

Dalam kegiatan ini dimulai dengan menampilkan beberapa representasi dari konsep yang disajikan secara eksplisit. Siswa bekerja melalui pertanyaan yang memandu mereka untuk mengeksplorasi representasi, mengembangkan pemahaman tentang itu, dan mengidentifikasi relevansi dan signifikansi.

Setelah konsep diidentifikasi dan dipahami, diperkuat dan diperluas dalam tahap "aplikasi". Pada tahap aplikasi, siswa menggunakan pengetahuan baru dalam latihan, masalah, dan bahkan situasi penelitian. "Latihan" memberi kesempatan peserta didik untuk membangun kepercayaan diri dalam situasi sederhana dan konteks yang yang dikenal. "Soal" membutuhkan peserta didik untuk menganalisis situasi yang kompleks, untuk mentransfer pengetahuan baru pada konteks yang tidak dikenal, untuk mensintesisnya dengan pengetahuan lain, dan untuk menggunakannya dalam cara-cara baru dan berbeda. "Pertanyaan Penelitian" memberi peluang bagi siswa untuk memperluas pembelajaran dengan mengangkat isu-isu, pertanyaan, atau hipotesis baru.

Peran Metakognisi. "Metakognisi" secara harafiah berarti "berpikir tentang berpikir." Ini termasuk manajemen diri dan self-regulasi, refleksi pembelajaran, dan penilaian kinerja sendiri. Inkuiri Terbimbing mengharuskan siswa untuk menggunakan metakognisi untuk membantu mereka menyadari bahwa mereka bertanggung jawab atas pembelajaran mereka sendiri dan mereka perlu memonitor itu 
(manajemen diri dan self-regulasi), bahwa mereka perlu untuk merefleksikan apa yang telah mereka pelajari dan apa yang mereka tidak atau belum pahami (refleksi atas pembelajaran), dan bahwa mereka harus berpikir tentang kinerja mereka dan bagaimana dapat ditingkatkan (penilaian diri) [4].

Pelaksanaan Inkuiri Terbimbing. Ada berbagai cara untuk menerapkan inkuiri terbimbing sesuai dengan pengajar, ukuran kelas, struktur kelas, dan budaya lokal. Semua pelaksanaan biasanya menggunakan siklus belajar: siswa bekerja sama dalam kelompok kecil pada kegiatan yang telah dirancang dengan cermat untuk membimbing mereka dalam membangun pemahaman dan dalam menerapkan pemahaman ini untuk memecahkan masalah. Dalam kelas inkuiri terbimbing pengajar bukanlah seorang pakar penyedia pengetahuan melainkan seorang pelatih atau fasilitator yang membimbing siswa dalam proses pembelajaran, membantu mereka untuk mengembangkan keterampilan proses dan pemahaman konseptual, dan menerapkan pemahaman ini dalam memecahkan masalah. Dalam konteks ini, pengajar memiliki empat peran yang harus dimainkan: pemimpin, monitor/asesor, fasilitator, dan evaluator.

Sebagai seorang pemimpin, pengajar menciptakan lingkungan belajar, ia mengembangkan dan menjelaskan pelajaran dan mendefinisikan tujuan (tujuan baik isi dan tujuan proses keterampilan), kriteria untuk sukses, dan perilaku yang diharapkan. Dia juga menetapkan struktur lingkungan, yaitu struktur tujuan/imbalan, struktur tim, struktur kelas, struktur ruang, dan struktur waktu.

Sebagai monitor/penilai, pengajar berkeliling kelas memantau dan menilai kinerja individu dan tim dan memperoleh informasi tentang pemahaman siswa, miskonsepsi, dan kesulitan dalam kolaborator orasi. Pengajar menggunakan informasi ini untuk meningkatkan kinerja.

Sebagai fasilitator, guru melakukan intervensi bila perlu dan pada saat yang tepat mengemukakan pertanyaan berpikir kritis (critical-thinking questions) untuk membantu tim memahami mengapa mereka kemungkinan akan mengalami kesulitan dan memikirkan apa yang harus mereka lakukan untuk meningkatkan dan membuat kemajuan. Pengajar harus campur tangan pada masalah proses, bukan masalah konten, dan mereka harus menyediakan jenis masukan yang mendorong pemikiran yang lebih dalam. Pertanyaan yang diajukan oleh pengajar harus membantu tim mengidentifikasi mengapa mereka mengalami kesulitan. Pertanyaan pertama harus terbuka dan umum; pertanyaan lebih lanjut harus lebih diarahkan dan spesifik sesuai kebutuhan. Pada akhir intervensi, tim harus diminta untuk merefleksikan proses: Apakah sumber dari kesulitan? Bagaimana Anda mengatasinya? Bagaimana Anda menghindari kesulitan dalam situasi yang sama di masa depan? Apa generalisasi yang dapat Anda buat untuk membantu Anda dalam situasi baru?

Sebagai evaluator, pengajar memberikan kata penutup pembelajaran dengan meminta anggota tim untuk melaporkan jawaban, untuk meringkas poin-poin utama, dan untuk menjelaskan strategi, tindakan, dan hasil kerja tim. Individu dan tim dievaluasi berdasarkan kinerja mereka, prestasi, dan efektivitas, sedangkan masalah umum dibagi dan menjadi tanggung jawab semua anggota kelas.

\section{Multiple Representation Chemistry Dalam Pendidikan Kimia}

Johnstone mengusulkan model untuk memahami masing-masing elemen inti yang digambarkan menggunakan tiga jenis representasi di mana ide-ide kimia dinyatakan [2], [3]. Menurut Johnstone [2]:

(a) the macro and tangible: what can be seen, touched and smelt;

(b) the submicro: atoms, molecules, ions and structures; and

(c) the representational: symbols, formulae, equations, molarity, mathematical manipulation and graphs", 


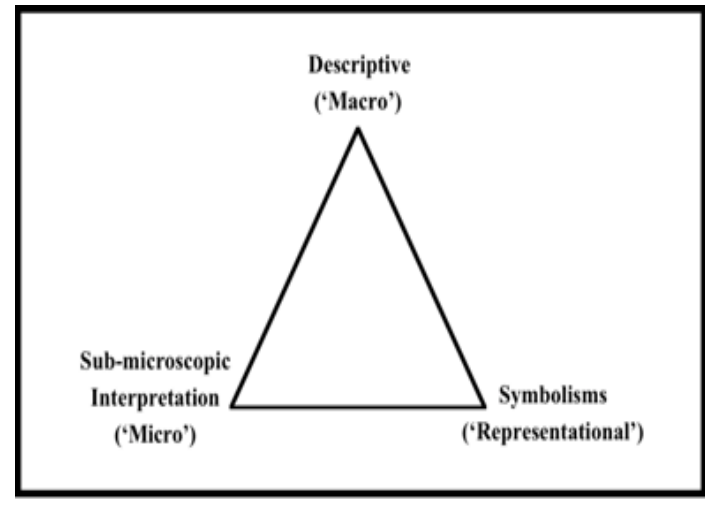

Gambar 1. Chemistry triangle [4]

Suatu gambar geometris segitiga planar sering (Gambar 1) digunakan pendidik kimia secara efektif dalam dekade terakhir untuk menjelaskan apa yang kita nilai dalam mengajar dan belajar tentang dunia atom dan molekul. Metafora ini telah membantu kita melihat bahwa tiga tingkatan pembelajaran (three learning levels), yaitu simbolis, makroskopik dan submikroskopis, atau molekul yang diperlukan untuk siswa untuk memahami kimia (5-7)

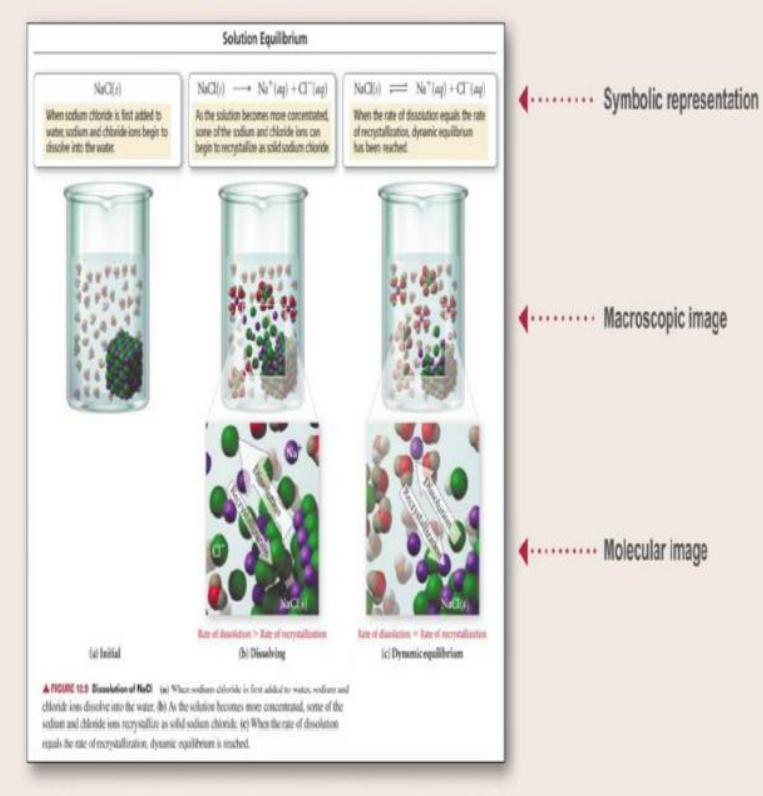

Gambar 2. Pelarutan garam $\mathrm{NaCl}$, pendekatan Chemistry triangle [14]

\section{Pentingnya Penguasaan Materi Prasyarat (Prior Kknowledge) dalam tingkatan "Chemistry triangle" Sebagai Strategi Dalam Pembelajaran Kimia}

Ketika kita mengajar, kita sering mencoba untuk meningkatkan pemahaman siswa terhadap materi yang dipelajari dengan menghubungkannya pada pengetahuan dan pengalaman dari pembelajaran sebelumnya atau dari kehidupan sehari-hari. Ketika masuk kelas siswa sudah mempunyai pengetahuan yang didapat pada pembelajaran lain dan melalui kehidupan harian. Pengetahuan awal ini terdiri dari gabungan fakta, konsep, model, persepsi, keyakinan, nilai, dan sikap [14].

Pengetahuan awal didefenisikan sebagai pengetahuan yang telah ada sebelum pelaksanaan tugas belajar tertentu, tersedia atau dapat dipanggil kembali atau direkonstruksi, relevan untuk pencapaian tujuan dari pembelajaran, disusun dalam skema yang terstruktur, untuk tingkat tertentu bersifat dapat dialihkan atau berlaku untuk tugas belajar lainnya dan bersifat dinamis [15]. Oleh karena itu, pengetahuan awal dapat didefenisiskan sebagai kombinasi pengetahuan dan keterampilan [15]

Dalam pembelajaran, idealnya, siswa membangun pengetahuan baru di atas fondasi yang kuat berupa pengetahuan awal (pengetahuan prasyarat), untuk membangun hubungan antara pengetahuan dengan pengetahuan baru sehingga membantu siswa membangun struktur pengetahuan yang semakin kompleks dan kuat.

Siswa menghubungkan apa yang sedang mereka pelajari dengan apa yang telah mereka ketahui, menginterpretasi informasi yang masuk dan melalui pengetahuan awal, keyakinan, dan asumsi mereka. [16]. Namun, sejauh mana siswa dapat memanfaatkan pengetahuan awal secara efektif untuk membangun pengetahuan baru tergantung pada keadaan pengetahuan awal mereka serta kemampuan instruktur (guru) untuk memanfaatkan itu

Menurut Mawardi [17], usaha penguasaan pengetahuan prasyarat dilakukan untuk meningkatkan keterlibatan siswa dalam proses pembelajaran kimia dengan memanfaatkan pengetahuan awal dan pengalaman keseharian siswa sebagai titik tolak dalam mendiskusikan atau menggali informasi (materi) baru yang akan dipelajari. Pengetahuan awal yang seharusnya telah dimiliki siswa berupa fakta dan konsep, prinsip disebut sebagai materi prasyarat untuk mempelajari materi pokok (pengetahuan) baru. 
Pengetahuan awal itu mungkin diperoleh melalui proses pembelajaran sebelumnya, pengalaman hidup "alam takambang jadi guru", atau dari intuisi.

\section{Kesimpulan}

Pengembangan Kurikulum 2013 untuk aspek konseptual menuntut metoda pembelajaran aktif, yang mengedepankan pengalaman personal melalui observasi, bertanya, melakukan asosiasi, menyimpulkan dan mengkomunikasikan. Kurikulum 2013 juga mengsyaratkan proses pembelajaran berpusat pada peserta didik, bersifat kontekstual dan buku teks memuat selain materi ajar, juga proses pembelajaran yang menggambarkan urutan yang rinci (sehingga menutup peluang penafsiran beragam, yang berujung pada pembelajaran berpusat pada guru), sistem penilaian serta kompetensi yang diharapkan.

Suatu kegiatan belajar yang menerapkan inkuiri terbimbing menggunakan siklus belajar yang terdiri dari tiga tahap atau fase, yaitu eksplorasi, penemuan konsep atau pembentukan, dan aplikasi konsep. Dalam pelaksanaanya menggunakan siklus belajar: siswa bekerja sama dalam kelompok kecil pada kegiatan yang telah dirancang dengan cermat untuk membimbing mereka dalam membangun pemahaman dan dalam menerapkan pemahaman ini untuk memecahkan masalah.

Berdasarkan analisis di atas dapat kita disimpulkan bahwa strategi inkuiri terbimbing merupakan salah strategi pembelajaran yang perlu disiapkan dalam mengimplemetasikan Kurikulum 2013 untuk Mata Pelajaran Kimia.

\section{Ucapan Terima Kasih}

Kepada LP2M Universitas Negeri Padang, yang telah mendanai Pengabdian Masyarakat ini

\section{Pustaka}

1.Puskur. Naskah Akademik : Kajian Kebijakan Kurikulum Mata Pelajaran IPA. Jakarta: Puskur, Balitbang Depdiknas; 2007.

2. Johnstone AH. Teaching of Chemistry Logical or Psychological. Chemistry
Eduation: Reseach and Practice in Europe. 2000;1(1):9-15.

3.Gilbert JK, Treagust D. Introduction: Macro, Submicro, and Symbolic Representaions and the Relationship Between Them: Key Models in Chemistry Education. Multiple Representaions inChemical Education: Springer; 2009.

4.Reid N. Working Memory and Science Education : Concusions and Implication. International Journal of Science Education. 2009;27(2):245-50.

5.Talanquer V. Macro, Submicro, and Symbolic: The many faces of the chemistry "triplet". International Journal of Science Education. 2011;33(2):179-95.

6. Aini, Faizah Qurratu. 2016. Development of Guided Inquiry Based Student Worksheet on the Chemical Equilibrium Topic for Chemistry Learning in $11^{\text {th }}$ Grade. International Conference on Teacher Learning and Development (ICLT). Malaysia

6. Aini, F. Q., Mawardi., and Oktavia, B. 2017. Guided Inquiry Based Student Worksheet on Chemical Equilibrium Topic. German: LAP Lambert Academic Publishing

7. Irham, S. M., Mawardi dan Oktavia, B. 2016. The Development of Guided Inquiri Based Worksheet on Colligative Properties Solution for Chemistry Learning". International Conference On Mathematics and Science Education

8. Piawi, K. , Umar Kalmar Nizar dan M. Mawardi. 2018. Development of student worksheet based on guided inquiry with class activity and laboratory in thermochemistry material. Proceeding of International Conferences on Education, Social Sciences and Technology

9. Rahmiati, S. dan M. Mawardi, 2016. "Teaching Materials Development of Student Worksheet (SWS) Guided Inquiry Based on the Materials for Learning Rate of Chemical Reaction". Proceedings of Academics World 
28th International Conference, 28th March 2016. Tokyo, Japan

10. Repdayanti, M. Mawardi, dan Budhi Oktavia. 2018. The Development of Student Worksheets based on Guided Inquiry by Class and Laboratory Activity for Reaction Rate Material at the 11th Grade in High School. International Journal of Progressive Sciences and Technologies (IJPSAT). Vol. 8 No. 2: 286-294

11. Zammiluni, Allizar Ulianas, dan M.

Mawardi. 2018. "Development of Guided Inquiry Based Work Sheet with Class and Laboratory Activity on Chemical Bonding Topic in Senior High School” International Journal of Chemistry Education Research. Vol. 22 lss. 2

12.Moore JW, Stanitski CL, Jurs PC. Chemistry: The Molecular Science,. 4th ed. Madison: Mary Finch; 2011.

13. Zumdahl SS, Zumdahl SA. Chemistry: An Atoms First Approach. Belmont: BROOK COLE Cengange Learning; 2012.

14. Tro NJ. Chemistry: a molecular approach. New Jersey: Pearson Prentice Hall; 2011.

15. Ambrose SA, Bridges MW, Lovett MC. How Does Students' Prior Knowledge Affect Their Learning? How Learning Works. San Francisco: John Wiley \& Son, Inc; 2010.

16. Hailikari T. Assessing University Students' Prior Knowledge, Implication for Theory and Practice. Finland: University of Helsinki Department of Education; 2009. Contract No.: Research Report 227.

17.Mawardi, 2011, Inovasi Dalam Pembelajaran Kimia, Proseding Seminar Nasional Kimia dan Pendidikan Kimia HKI Cab. Sumatera Barat: ISBN: 978-602-8821-28-5; 